\title{
ANALYSIS OF THE STATE OF THE ACCIDENT RATE IN THE CONSTRUCTION INDUSTRY IN EUROPEAN UNION COUNTRIES
}

\author{
B. HOŁA ${ }^{1}$, M. SZÓSTAK ${ }^{2}$
}

\begin{abstract}
The article presents an analysis and evaluation of the accident rate in selected European Union countries. On the basis of available statistical data, the analysis of accidents in various sectors of the European Union economy was carried out. Afterwards, a ranking of countries regarding accidents in the construction industry was developed. For the selected representative countries, analysis of changes in the indicators which characterize the accident rate during the period between 2008 and 2012 was carried out. Conclusions resulting from the conducted research were formulated.
\end{abstract}

Keywords: European Union, construction industry, accident at work, accident rate

\section{INTRODUCTION}

Statistical data published by the Statistical Office of the European Union and also information contained in numerous publications are the basis for the statement that the construction industry, when compared to other sections of the national economy, is characterized by a high level of hazards to human life and health and also to a high accident rate. The high accident rate in the construction industry is a phenomenon that occurs not only in the European Union countries, but it is also noticeable in other countries of the world $[1,3,6]$. Statistics of accidents at work play an important role in the assessment of the safety state in various countries in the world, their sections of the national economy and enterprises.

\footnotetext{
1 Ph.D. D.Sc. Eng. Prof. WUT, Wrocław University of Technology, Faculty of Civil Engineering, Wybrzeże Wyspiańskiego 27, 50-370 Wrocław, e-mail: bozena.hola.@pwr.edu.pl

${ }^{2}$ M.Sc. Eng., Wrocław University of Technology, Faculty of Civil Engineering, Wybrzeże Wyspiańskiego 27, 50-370 Wrocław, e-mail: mariusz.szostak@pwr.edu.pl
} 
Having such statistics makes it possible to formulate a variety of indicators that can be used in the assessment of the accident rate and for conducting various comparative analyses in the area of accident rate evaluation. The article presents an analysis and evaluation of accidents in selected European Union countries. On the basis of available statistical data, an analysis of accidents in various sectors of the European Union economy was carried out. The aim of this analysis was to determine the position of the construction industry in the ranking of all sections. Afterwards, a ranking of countries regarding the accident rate in the construction industry was developed. For each of the selected representative countries, analysis of changes in the indicators which characterize accidents in the construction industry and conclusions resulting from the carried out research were formulated.

\section{TERMS USED IN ASSESSMENT OF THE ACCIDENT RATE}

The accident rate is a phenomenon of employees undergoing accidents at work. It can be estimated as the sum of accidents occurring at some time, usually within a year, which is presented by various indicators $[8,11]$.

From the literature research it can be concluded that in the individual countries of the European Union different methodologies of collecting statistical data regarding accidents at work are assumed $[2,4,7,9,10]$. Methodological differences concern the extent of recording accidents, namely:

- recognition of road accidents that were associated with work as accidents at work,

- registering self-employed people as injured in accidents at work,

- the level of the declaration of accidents at work,

- activities included in reports.

Differences also occur in the rules of registering fatal accidents. For example:

- In the Netherlands, an accident is registered as fatal if the victim's death occurs on the day of the accident,

- In Germany, if the death occurs within 30 days of the accident,

- In Spain, if the victim dies within 1.5 years,

- In Poland, if the victim dies within 6 months of the date of the accident,

Due to the above reasons, statistical data from individual countries cannot be compared. In order to make it possible, work that aims to standardize the rules of collecting information about accidents at work has been carried out for the last several years. This work is co-ordinated by the Statistical Office of the European Union (EUROSTAT) and the Directorate General for Employment, Social Affairs and Inclusion of the European Commission [9]. 
According to the definition developed by EUROSTAT [4], an accident at work is a sudden event during the time of work, which results in physical or mental injury. The phrase "during the time of work" means that the accident occurs "when executing professional activity or during the time at work". The definition of an accident at work also includes accidents that occur during the time of work but are outside of the office, even if they are caused by third parties and even during transport, including road accidents and cases of acute poisoning. The scope work related accidents, as it is in Poland, does not cover accidents on the way to or from work as they are treated as a separate, defined by law, accident on the way to and from work.

The criterion for registering an accident at work is the number of days of incapacity. In the methodology used by EUROSTAT the only recorded accidents are ones which caused more than three days off from work apart from the day on which the accident occurred. A fatal accident at work is an accident which results in death in a period not exceeding one year from the date of the accident. Statistical data regarding accidents at work refers to the population of employed people covering both- those who work for public and private employers and who receive benefits for fulfilled services in the form of: weekly or monthly salaries, bonuses, payments for obtained results at work or in the form of an exchange of goods or services as a form of non-cash payment.

\section{RESEARCH METHODOLOGY}

The number of countries that are members of the EU has changed over the past several years. The European Union currently has 28 Member States. The founding members are: Belgium, Denmark, Finland, France, Greece, Spain, the Netherlands, Ireland, Luxembourg, Germany, Portugal, Sweden, United Kingdom and Italy (EU15).

On the $1^{\text {st }}$ of May 2004 the area of the European Union increased by another 10 countries (EU25) which included: Cyprus, Czech Republic, Estonia, Latvia, Lithuania, Malta, Poland, Slovakia, Slovenia and Hungary. On the $1^{\text {st }}$ of January 2007 the area of the European Union expanded and included Romania and Bulgaria (EU27) and on the $1^{\text {st }}$ of July 2013 Croatia (EU28) officially joined the European Union. Since the procedure of obtaining statistical data takes three years, only data from 27 Member States can be currently found in the resources of EUROSRAT. Therefore such a set of countries was included in the research.

The research was divided into three stages, namely:

- The first stage involved the location of the construction industry with regards to the accident rate among all sectors of the economy of the whole Community. The economy of the European Union 
and the Member States is divided into 19 sections. The study was conducted for statistical data obtained for 2012 .

- The second stage involved the ranking of 27 Member States of the European Union with regards to the accident rate in the construction industry. The research was conducted for statistical data obtained for the year 2012.

- The third stage involved the building of models of accident trends in the construction industry for the representative countries selected from the set of EU27. The time interval covered by the study included the years between 2008 and 2012. Countries that joined the EU in 2004 were selected from the set of Member States. The accident rate in selected countries was shown compared to the accident rates in the EU27.

The analysis included the following statistics: the number of people injured in accidents at work in the construction industry and frequency rates of accidents at work in relation to 100,000 employees. The number of people injured in accidents at work in the construction industry $N P_{i}$ is described by the following formula:

$$
N P_{i}=\sum_{j=1}^{M} n p_{i, j}
$$

where:

$n p_{i, j}$ - is the number of people injured in $j$ accident at work in the construction industry in the year $t_{i}$, $M$ - is the number of all accidents at work in the construction industry in the year $t_{i}$.

The frequency rate of accidents determines the number of people injured in accidents at work in the assessed year $t_{i}$ for every 100,000 employees and it is described by the following relation:

$$
f_{i, k, 100000}=\frac{n p_{i, k}}{n e_{i}} \cdot 100000, \quad i=1, \ldots . ., N, k=1,2,
$$

where:

$n p_{i, k}$ - is the number of people injured in accidents at work in the construction industry in the $t_{i}$ year, where:

$k=1$ refers to accidents which cause more than three days of absence from work,

$k=2$ refers to fatal accidents,

$n e_{i}$-is the number of employees in the construction industry in the $t_{i}$ year. 
The value of this rate indicates the level of occupational risks associated with the implementation of construction works.

\section{ANALYSIS OF THE ACCIDENT RATE IN EU COUNTRIES}

Graphs illustrating the accident rate in the construction industry in European Union countries were developed based on the statistical data published by EUROSTAT [5]. This data was generated with the use of the Data Explorer application.

\subsection{THE ACCIDENT RATE IN THE UE IN COMPARISON WITH OTHER SECTIONS OF THE ECONOMY}

Figure 1 shows the total number of accidents at work resulting in more than three days of absence from work which occurred in 2012 in the 27 European Union countries in different sectors of the economy. It may be noted that the construction industry (section F), in terms of the total number of accidents, occupies second place among all sections of the national economy, just behind industrial manufacturing (section C). The presented statistical data shows that in the construction industry more than 1,100 accidents at work happen every day in all countries from the EU27.

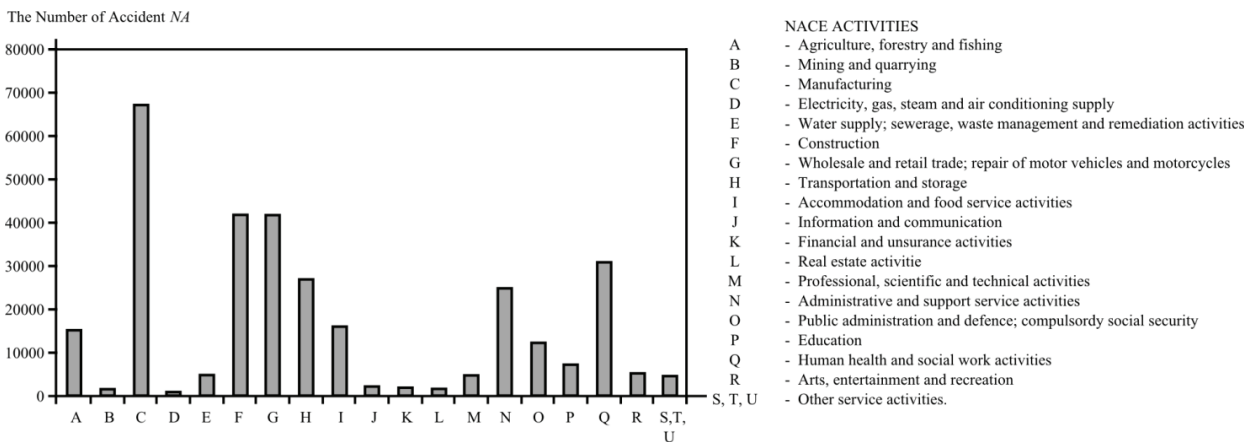

Fig. 1. The total number of accidents at work resulting in more than three days of absence from work in 2012 in various sectors of the EU27 economy

It should be noted that the total number of accidents at work does not reflect the scale of the accident rate in the various sectors of the economy. Frequency rates of accidents in relation to the number of 
employees need to be calculated in order to be able to compare data related to the accidents at work in different member states of the EU27.

Figure 2 shows frequency rates of accidents at work resulting in more than three days of absence from work which occurred in 2012 in the various sectors of the EU27 economy, while Figure 3 shows the frequency indicator of fatal accidents at work that occurred in 2012 in the individual EU27 economy sections. Symbols which refer to individual sections of the economy are the same as in Figure 1.

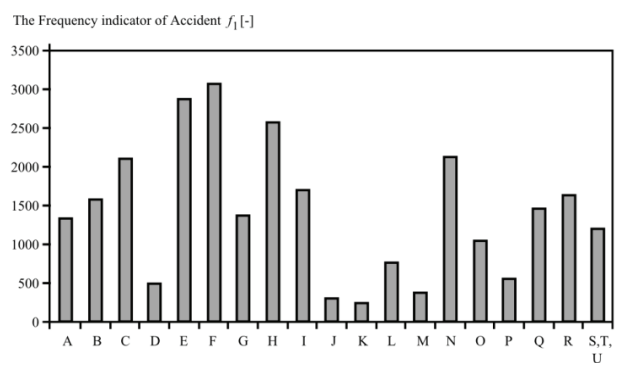

Fig. 2. The frequency indicator of accidents at work which resulted in more than three days of absence from work in relation to 100,000 employees in various sectors of the EU27 economy in 2012

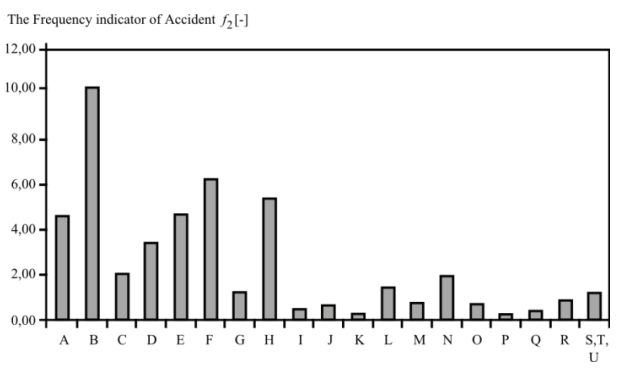

Fig. 3. The frequency indicator of fatal accidents at work in relation to 100,000 employees in various sectors of the EU27 economy in 2012.

The above charts show that the construction industry places first regarding accidents causing more than three days of absence from work and in second place in terms of the frequency rate of fatal accidents at work.

The presented data also shows that on average in the EU27 countries, for every 100,000 people employed in the construction industry, 3,000 people undergo accidents at work which cause at least three days of absence from work, and six people per each 100,000 of employees fall victim to fatal accidents. The presented rankings and numbers confirm the theory about the high-risk to life and health in the construction industry. 


\subsection{COMPARATIVE ANALYSIS OF THE ACCIDENT RATE IN INDIVIDUAL EU COUNTRIES}

\subsubsection{NUMBER OF ACCIDENTS}

Figure 4 shows the ranking of the EU27 countries regarding the number of people injured in accidents which caused more than three days of absence from work and which occurred in 2012 in all sectors of the economy. Figure 5 shows the ranking of the EU27 countries regarding the number of people injured in accidents which caused more than three days of absence from work and which occurred in 2012 in the construction industry.

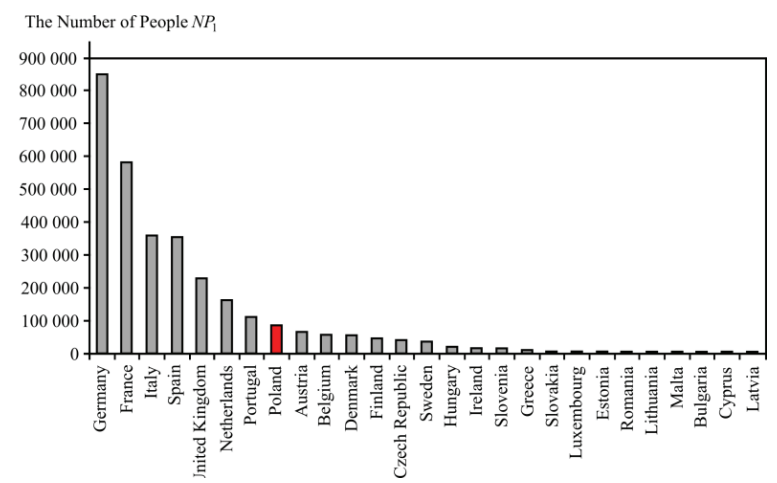

Fig. 4. The number of people injured in accidents at work which resulted in more than three days of absence from work in 2012 in all sectors of the economy of each EU27 country

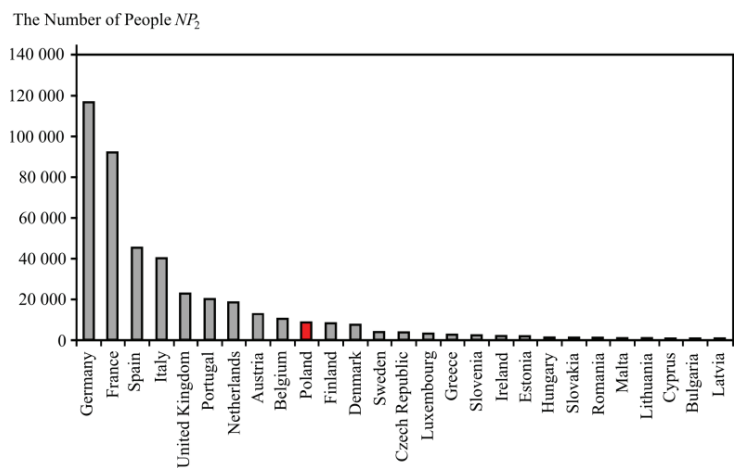

Fig. 5. The number of people injured in accidents at work which resulted in more than three days of absence from work in 2012 in the construction industry of each EU27 country 
Figure 4 shows that the greatest number of accidents, which in 2012 resulted in absence from work for more than three days, occurred in Germany and was equal to 855,181 people injured. In France it was equal to 587,666 injured people, in Italy equal to 359,967 injured people and in Spain equal to 356,110 injured people. In this ranking Poland is in the $8^{\text {th }}$ position with the number of injured people equal to 87,095 .

When analysing Figure 5 regarding the construction sector it can be noted that the highest number of accidents in the construction industry also occurred in Germany and amounted to 117,006 injured people and respectively in France to 92,268 injured people, in Spain to 44,960 injured people and in Italy to 39,975 injured people. In this ranking Poland ranks in the $10^{\text {th }}$ place with the number of people injured in accidents equal to 7,961 .

\subsubsection{THE FREQUENCY RATE OF ACCIDENTS IN RELATION TO 100,000 EMPLOYEES}

As already mentioned, the number of accidents at work is not a reliable indicator for the assessment of the accident rate in the construction industry in each country. Therefore, data regarding accident frequency rates in relation to 100,000 people employed in the construction industry is provided below. Figure 6 includes the values of the frequency rate of accidents at work which resulted in more than three days of absence from work and which occurred in 2012 in all countries of the EU27, while Figure 7 includes values of the frequency rate of fatal accidents at work which happened in 2012 in all countries of the EU27.

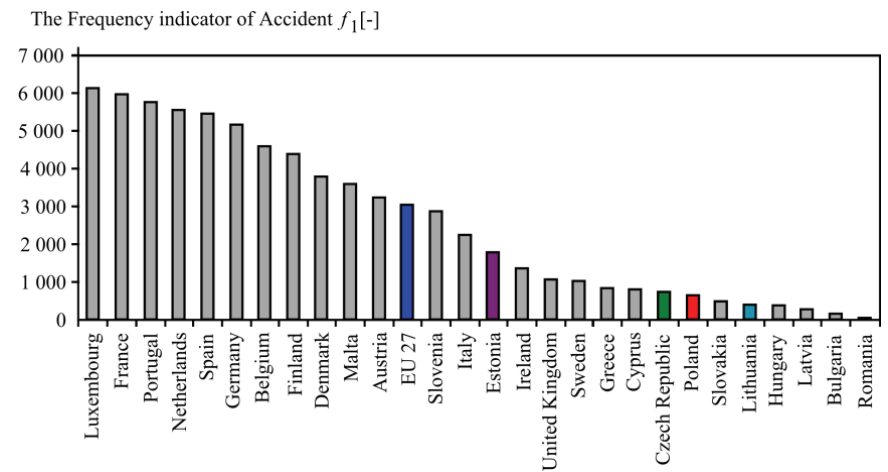

Fig. 6. The frequency rate of accidents at work which resulted in more than three days of absence from work and occurred in 2012 in all countries of the EU27 


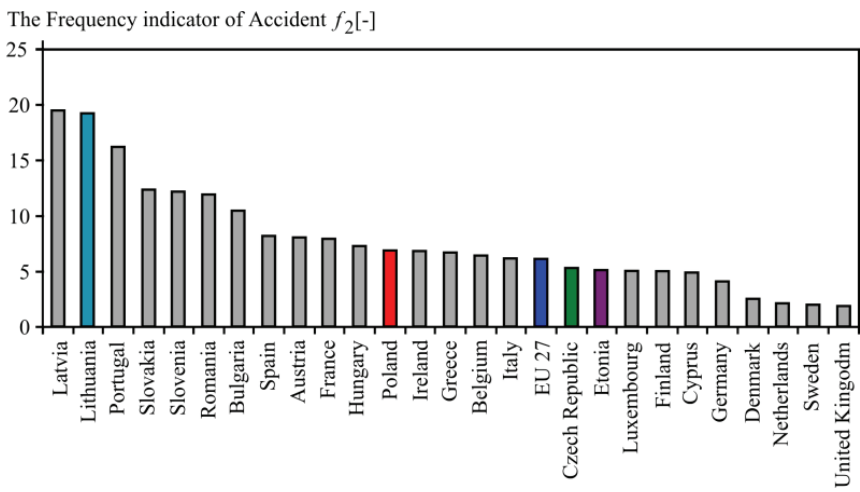

Fig. 7. The frequency rate of fatal accidents at work which happened in 2012 in the construction industry in all countries of the EU27

When comparing data regarding the accident indicator presented in Figure 6 it can be stated that in the Polish construction industry in 2012, for every 100,000 employees 674 people suffered accidents at work which resulted in more than three days of absence from work. This number is much lower than the average value for all the EU27 countries which is equal to 3044. In the presented ranking Poland is in a favourable $22^{\text {nd }}$ place.

The greatest value of the accident frequency indicator was recorded in Luxembourg and the lowest in Romania. A less favourable result was obtained for statistical data regarding the frequency rate of fatal accidents which was shown in Figure 7.

The value of this rate for the Polish construction industry in 2012 was equal to 7.01 injured people per 100,000 employees and it ranked Poland in the $12^{\text {th }}$ position. The value of this rate for all the EU27 countries was equal to 6.22 injured people per 100,000 employees. The highest value of this indicator was recorded in Latvia, and the lowest in the UK.

\subsubsection{ANALYSIS OF CHANGES OF VALUES OF THE ACCIDENT FREQUENCY RATE IN SELECTED EU27 COUNTRIES}

An analysis of changes in the values of the accident frequency rate was carried out for the EU27 countries and for Poland, Lithuania, Estonia and the Czech Republic. These countries were selected from those that joined the European Union on May $1^{\text {st }} 2004$. The research interval covered the years from 2008 to 2012. Unfortunately, statistical data published by EUROSTAT does not include the period from 2004 to 2007. Figure 8 shows the course of changes in the values of the frequency rate of accidents that caused more than three days of absence from work which occurred in the selected 
EU27 countries, while Figure 9 shows the course of changes in values of the frequency rate of fatal accidents in the selected EU27 countries.

Figure 8 shows that values of frequency rates of accidents that caused more than three days of absence from work in all of the analysed countries throughout the whole assessed period are lower than the values obtained for the EU27countries. It can also be noted that the developing trend of the frequency of these accidents in all the mentioned countries and in the EU27 countries has a favourable downward tendency.

However, Figure 9 shows that the majority of frequency rates of fatal accidents during the studied time period in the assessed countries reached higher values than in the EU27 countries.

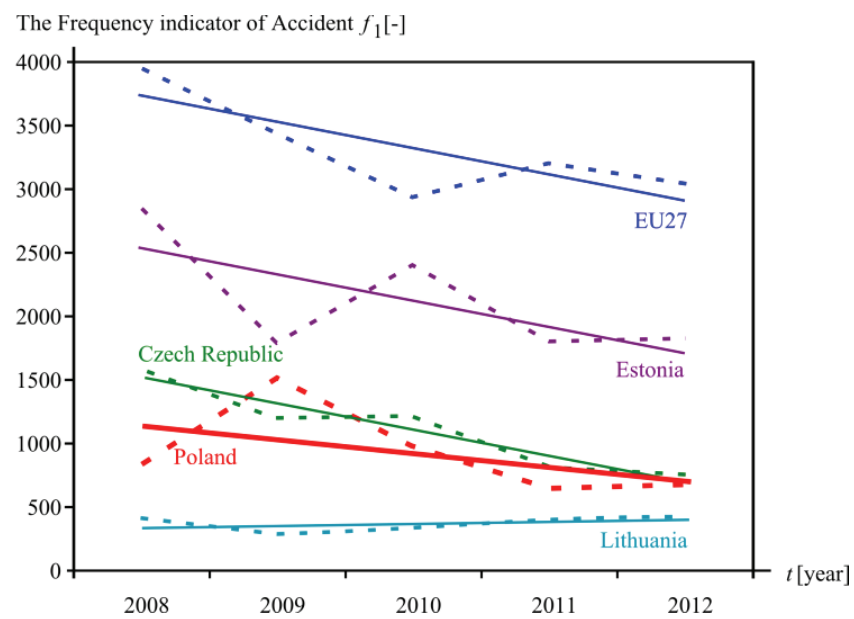

Fig. 8. The course of changes in time of the frequency rate of accidents at work in the construction industry that caused more than three days of absence from work and occurred in the selected EU27 countries

The fact that in 2012 the value of this rate for the Czech Republic and Estonia is lower than the value for the EU27 countries, and for Poland this value is only a little higher is comforting. In these countries a downward trend of the studied phenomenon is noticeable. However, the significant increase of this rate in Lithuania, where the development trend has a definite rising tendency, is worrying. 


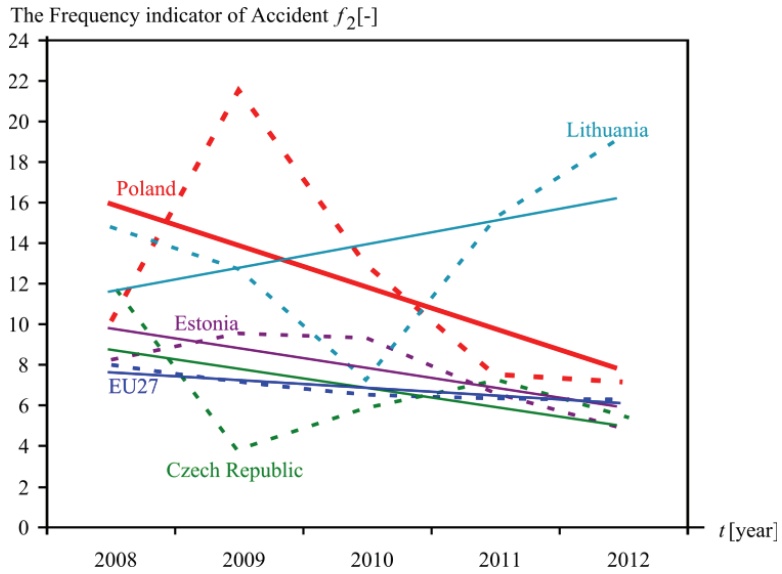

Fig. 9. The course of changes in time of the frequency rate of fatal accidents at work in the construction industry in selected countries

\section{CONCLUSiOnS}

Results of research and analysis presented in this paper allow for the following conclusions regarding the phenomenon of the accident rate in the construction industry of European Union countries to be formulated:

- Statistical data regarding accidents at work are the basis for the statement that the construction industry is one of the most accident prone sectors of the economy in the European Union. The number of accidents at work that result in more than three days of absence from work, amounts to 418,693 injured people in 2012 and it puts the construction industry in the second place among the most accident prone sections.

- The number of people injured in accidents at work in the construction industry is not a reliable value for accidental rate value evaluation.. In the assessment of the accident situation, accident frequency rates are useful as they present the number of injured people per 100,000 employees. Thus, the frequency rate of accidents that resulted in more than three days of absence from work has placed the construction industry in the first place among all sections of the EU27 economy, while the accident frequency rate of fatal accidents puts it in the second place.

- When analysing accidents in different countries of the European Union and the position of Poland in this ranking, it can be concluded that:

$\checkmark$ Poland ranks in 10th place among all the EU27 countries in terms of the number of people 
injured in accidents at work which resulted in more than three days of absence from work and which occurred in 2012 in the entire economy.

$\checkmark$ Poland ranks in $10^{\text {th }}$ place among all the EU27 countries in terms of the number of people injured in accidents at work which resulted in more than three days of absence from work and which occurred in 2012 in the construction sector

$\checkmark$ The highest number of people injured in such accidents was reported in Germany, and the lowest in Latvia.

- In terms of the frequency rate of accidents at work which resulted in more than three days of absence from work and which occurred in 2012 in the construction sector, Poland is in a favourable $22^{\text {nd }}$ place, however, in terms of the frequency rate of fatal accidents in the construction industry from 2012, Poland is in a less favourable $12^{\text {th }}$ place in the ranking of the EU27 countries.

When analysing changes in the values of accident frequency rates in the time period which covers the years from 2008 to 2012 it must be stated that the frequency rate of accidents that result in more than three days of absence from work, presents a downward trend for Poland, Estonia, the Czech Republic and Lithuania. The values of this rate during the studied period of time are lower than the values obtained for all the EU27 countries. The frequency rate of fatal accidents for Poland, the Czech Republic and Estonia also shows a favourable declining tendency while this rate for Lithuania shows a rise in the negative tendency. It should be noted, however, that the studied time interval is too short to enable a constant trend in the development of the assessed phenomena to be noted. 


\section{REFERENCES}

1. Akhad Suraji, A. Roy Duff, Stephen J. Peckitt, Development of causal Model of construction accident causation, Journal of construction engineering and management, juy/august, 2001, 337-344.

2. Bojanowski R., A new statistical card of an accident at work. Occupational Safety, 7-8, 2005.

3. Carlos A. Arboleda, Dlulcy m. Abraham, Fatalities in Treching Operations - Analysis Using Models of Accident Causation, Journal of construction engineering and management, ASCE/ march/april 2004, 273-280.

4. European Statistics on Accident at work (ESAW) Summary methodology. Eurostat Methodologies \& Working papers, European Union, 2013.

5. EUROSTAT - European Commission - Database http://ec.europa.eu/eurostat/data/database (Retrieved April 2015).

6. Ivan W. H. Fung, Vivian W.Y. Tam, Tommy Y. Lo, Lori L.H.Lu, Developing a Risk Assessment Model or construction safety, International journal of Project Management.

7. Kassyk-Rokicka H., Statistics are not difficult. PWE, Warsaw 1986.

8. Lis T., Nowacki K., Management of occupational health and safety in an industrial enterprise. Publisher of the Silesian University of Technology, Gliwice, Poland 2005.

9. Pawłowska Z., Harmonization of statistics from the area of accidents at work in European countries. Occupational Safety, 10, 2002.

10. Pawłowska Z., Accidents at work according to estimations of the International Labour Organisation. Occupational Safety, 3, 2005, 8-11.

11. Studenśki R.,Organization of safe work in an enterprise. Publisher of the Silesian University of Technology, Gliwice, Poland 1996. 


\section{LIST OF FIGURES AND TABLES:}

Fig. 1. The total number of accidents at work resulting in more than three days of absence from work in 2012 in various sectors of the EU27 economy.

Rys. 1. Ogólna liczba wypadków przy pracy w 2012 roku w poszczególnych sekcjach gospodarki EU27.

Fig. 2. The frequency indicator of accidents at work which resulted in more than three days of absence from work in relation to 100,000 employees in various sectors of the EU27 economy in 2012.

Rys. 2. Wskaźnik częstości wypadków przy pracy, które skutkowały więcej niż trzema dniami nieobecności w pracy w odniesieniu do 100000 zatrudnionych w poszczególnych sekcjach gospodarki EU27, w 2012 r.

Fig. 3. The frequency indicator of fatal accidents at work in relation to 100,000 employees in various sectors of the EU27 economy in 2012.

Rys. 3. Wskaźnik częstości śmiertelnych wypadków przy pracy w odniesieniu do 100000 zatrudnionych w poszczególnych sekcjach gospodarki EU27, w 2012 r.

Fig. 4. The number of people injured in accidents at work which resulted in more than three days of absence from work in 2012 in all sectors of the economy of each EU27 country.

Rys. 4. Ogólna liczba osób poszkodowanych w wypadkach przy pracy we wszystkich sekcjach gospodarki narodowej w 2012 roku w poszczególnych krajach EU27.

Fig. 5. The number of people injured in accidents at work which resulted in more than three days of absence from work in 2012 in the construction industry of each EU27 country.

Rys. 5. Ogólna liczba osób poszkodowanych w wypadkach przy pracy w budownictwie w 2012 roku w poszczególnych krajach EU27.

Fig. 6. The frequency rate of accidents at work which resulted in more than three days of absence from work and occurred in 2012 in all countries of the EU27.

Rys. 6. Wskaźnik częstości wypadków przy pracy powodujących więcej niż 3 dni nieobecności w pracy w roku 2012 dla budownictwa w poszczególnych krajach EU27.

Fig. 7. The frequency rate of fatal accidents at work which happened in 2012 in the construction industry in all countries of the EU27.

Rys. 7. Wskaźnik częstości wypadków przy pracy o skutkach śmiertelnych w roku 2012 dla budownictwa w poszczególnych krajach EU27.

Fig. 8. The course of changes in time of the frequency rate of accidents at work in the construction industry that caused more than three days of absence from work and occurred in the selected EU27 countries.

Rys. 8. Przebieg zmian w czasie wskaźnika częstości wypadków przy pracy w budownictwie powodujących więcej niż 3 dni nieobecności w pracy w wybranych krajach UE27.

Fig. 9. The course of changes in time of the frequency rate of fatal accidents at work in the construction industry in selected countries

Rys. 9. Przebieg zmian w czasie wskaźnika częstości wypadków śmiertelnych przy pracy w budownictwie w wybranych krajach. 


\title{
ANALIZA STANU WYPADKOWOŚCI W BUDOWNICTWIE W KRAJACH UNII EUROPEJSKIEJ
}

\author{
Słowa kluczowe: Unia Europejska, budownictwo, wypadek przy pracy, wypadkowość
}

\section{STRESZCZENIE:}

Dane statystyczne publikowane przez Urząd statystyczny Unii Europejskiej, a także informacje zawarte w licznych publikacjach są podstawą stwierdzenia, że budownictwo w porównaniu do pozostałych sekcji gospodarki narodowej charakteryzuje się wysokim poziomem zagrożeń dla życia i zdrowia człowieka oraz wysoką wypadkowością. W ocenie stanu bezpieczeństwa w poszczególnych państwach świata, sekcjach gospodarki narodowej oraz przedsiębiorstwach, ważną rolę odgrywają statystyki wypadków przy pracy.

Przedmiotem artykułu jest analiza i ocena wypadkowości w wybranych krajach Unii Europejskiej. Na podstawie dostępnych danych statystycznych, przeprowadzono analizę wypadkowości w poszczególnych sekcjach gospodarki Unii Europejskiej. Celem tej analizy było określenie pozycji budownictwa w rankingu wszystkich sekcji. Następnie opracowano ranking państw pod względem wypadkowości w budownictwie. Dla wybranych reprezentatywnych państw przeprowadzono analizę zmian wartości wskaźników charakteryzujących wypadkowość w budownictwie oraz sformułowano wnioski wynikające z przeprowadzonych badań

Badania podzielono na trzy etapy, a mianowicie:

- $\quad$ Etap pierwszy polegał na umiejscowieniu budownictwa pod względem wypadkowości wśród wszystkich sekcji gospodarki całej Wspólnoty. Gospodarka Unii Europejskiej i państw członkowskich podzielona jest na 19 sekcji. Badania przeprowadzono dla danych statystycznych uzyskanych dla 2012 roku.

- $\quad$ Etap drugi polegał na uszeregowaniu 27 państw członkowskich Unii Europejskiej pod względem wypadkowości w budownictwie. Badania przeprowadzono dla danych statystycznych pozyskanych dla 2012 roku.

- $\quad$ Etap trzeci polegał na zbudowaniu modeli tendencji wypadkowej w budownictwie dla państw reprezentatywnych wybranych ze zbioru EU27. Przedział czasu objęty badaniem obejmował lata od 2008 do 2012 roku. Ze zbioru państw członkowskich wybrano państwa, które przystąpiły do UE w 2004 r. Wypadkowość w wybranych państwach przedstawiono na tle wypadkowości w EU27.

Przedstawione w artykule wyniki badań i analiz pozwalają na sformułowanie następujących wniosków dotyczących zjawiska wypadkowości w budownictwie krajów stowarzyszonych w Unii Europejskiej:

- Dane statystyczne dotyczące wypadków przy pracy są podstawą stwierdzenia, że budownictwo jest jedną z bardziej wypadkogennych sekcji gospodarki w Unii Europejskiej. Liczba wypadków przy pracy skutkujących więcej niż trzema dniami absencji w pracy, wynosząca 418693 osób poszkodowanych w 2012 roku, stawia budownictwo na drugim miejscu wśród najbardziej wypadkogennych sekcji.

- $\quad$ Liczba osób poszkodowanych w wypadkach przy pracy w budownictwie nie jest wielkością miarodajną do oceny wypadkowości. W ocenie sytuacji wypadkowej przydatne są wskaźniki częstości wypadków przedstawiające liczbę osób poszkodowanych na każde 100 tys. osób zatrudnionych. I tak, wskaźnik częstości wypadków, które spowodowały więcej niż 3 dni nieobecności w pracy usytuował budownictwo na pierwszym miejscu, natomiast wskaźnik częstości wypadków śmiertelnych usytuował budownictwo na drugim miejscu wśród wszystkich sekcji gospodarki EU27.

- Analizując wypadkowość w poszczególnych krajach Unii Europejskiej oraz miejsce Polski w tym rankingu można stwierdzić, że: 
$\checkmark$ pod względem liczby osób poszkodowanych w wypadkach przy pracy skutkujących więcej niż trzema dniami absencji w pracy, które zdarzyły się w 2012 roku w całej gospodarce, Polska plasuje się na 8 miejscu wśród wszystkich państw EU27.

$\checkmark$ pod względem liczby osób poszkodowanych w wypadkach przy pracy skutkujących więcej niż trzema dniami absencji w pracy które zdarzyły się w 2012 roku w budownictwie, Polska plasuje się na 10 miejscu wśród wszystkich państw EU27.

$\checkmark$ największą liczbę osób poszkodowanych w takich wypadkach odnotowano w Niemczech, a najmniejszą na Łotwie.

- $\quad$ Pod względem wskaźnika częstości wypadków przy pracy powodujących więcej niż 3 dni nieobecności w pracy, które zdarzyły się w 2012 roku w budownictwie, Polska plasuje się na korzystnym 22 miejscu, natomiast pod względem wskaźnika częstości wypadków śmiertelnych w roku 2012 w budownictwie, Polska plasuje się na mniej korzystnym 12 miejscu w rankingu państw EU27.

- Analizując zmiany wartości wskaźników częstości wypadków w przedziale czasu obejmującego lata od 2008 roku do 2012 roku należy stwierdzić, że wskaźnik częstości wypadków skutkujących więcej niż trzema dniami absencji w pracy dla Polski, Estonii, Republiki Czeskiej i Litwy wykazuje tendencję spadkową. Wartości tego wskaźnika w całym badanym przedziale czasu są niższe od wartości uzyskanej dla wszystkich krajów EU27. Wskaźnik częstości wypadków śmiertelnych dla Polski, Republiki Czeskiej i Estonii wykazuje również korzystną tendencję malejącą natomiast wskaźnik ten dla Litwy wykazuje niekorzystną tendencję rosnąca. Należy jednak zauważyć, że badany przedział czasu jest zbyt krótki, aby można było zauważyć trwałą tendencję w rozwoju badanych zjawisk. 